Marginal Modernity 
This page intentionally left blank 


\section{Marginal Modernity}

THE AESTHETICS OF DEPENDENCY

FROM KIERKEGAARD TO JOYCE

Leonardo F. Lisi

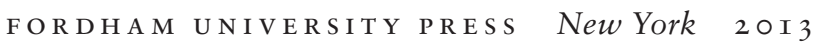




\section{$\mathrm{ML}$}

THIS BOOK IS MADE POSSIBLE BY A COLLABORATIVE GRANT

FROM THE ANDREW W. MELLON FOUNDATION.

Copyright (C) 2013 Fordham University Press

All rights reserved. No part of this publication may be reproduced, stored in a retrieval system, or transmitted in any form or by any means-electronic, mechanical, photocopy, recording, or any otherexcept for brief quotations in printed reviews, without the prior permission of the publisher.

Fordham University Press has no responsibility for the persistence or accuracy of URLs for external or thirdparty Internet websites referred to in this publication and does not guarantee that any content on such websites is, or will remain, accurate or appropriate.

Fordham University Press also publishes its books in a variety of electronic formats. Some content that appears in print may not be available in electronic books.

Library of Congress Cataloging-in-Publication Data

Lisi, Leonardo F.

Marginal modernity : the aesthetics of dependency from Kierkegaard to Joyce / Leonardo F. Lisi. — Ist ed. p. cm.

Includes bibliographical references and index.

ISBN 978-0-8232-4532-I (cloth : alk. paper)

I. Modernism (Literature) 2. Dependency

(Psychology) in literature. 3. Aesthetics in literature. 4. Philosophy in literature. I. Title.

$$
\mathrm{PN}_{5} 6 . \mathrm{M}_{54} \mathrm{~L}_{57} 20 \mathrm{I}_{3}
$$

$809^{\prime} .9 \mathrm{II} 2-\mathrm{dc} 23$

Printed in the United States of America

$$
\text { I5 I4 I3 } 54322 \text { I }
$$

First edition 
For Emily-

Lad saa Gud beholde Himlen, naar jeg maa beholde hende. 
This page intentionally left blank 